\title{
PENERAPAN AHLI WARIS PENGGANTI MENURUT KHI DAN KUHPERDATA DI KABUPATEN BONE (STUDI KASUS DI PENGADILAN AGAMA WATAMPONE
}

\author{
Suwardi Bahtiar \\ Universitas Islam Negeri (UIN) Alauddin Makassar \\ Email: suwardibahtiar@gmail.com
}

\begin{abstract}
Endowment system according to hukumadat in Sub-Province of Bone that is division of inappropriate heritage part of which its is it him accepted, in division of heritage finished upon mutual consensus without passing Justice of local Religion. Pursuant to Section 185 sentence (1), one can heir because replacement of place is one who is replaced by its child should have passed away in advance from heir and also one who is replaced by its child represent heir of andaikata he above the ground. Besides, top-drawer condition is that heir goodness which in fact and also substitution heir have to believe in Islam.
\end{abstract}

Keyword : Heir Substitution

\begin{abstract}
Abstrak
Sistem pewarisan menurut hukumadat di Kabupaten Bone yaitu pembagian warisan tidak sesuai bagian yang semestinya diterima, dalam pembagian warisan diselesaikan secara musyawarah tanpa melalui Pengadilan Agama setempat. Berdasarkan Pasal 185 ayat (1), seseorang dapat mewaris karena penggantian tempat adalah orang yang digantikan oleh anaknya tersebut harus sudah meninggal dunia lebih dahulu dari pewaris serta orang yang digantikan oleh anaknya tersebut merupakan ahli waris andaikata ia masih hidup. Selain itu, syarat yang paling penting adalah bahwa baik pewaris yang sebenarnya maupun ahli waris pengganti harus beragama Islam.
\end{abstract}

Kata Kunci : Ahli Waris Pengganti

Jurisprudentie | Volume 5 Nomor 1 Juni 2018 


\section{LATAR BELAKANG MASALAH}

N Tegara Indonesia merupakan negara kesatuan yang terdiri atas berbagai $\mathrm{N}$ macam suku bangsa, budaya, agama dan bahasa. Keanekaragaman tersebut berpotensi menimbulkan benturan-benturan di dalam masyarakat sebagai akibat dari adanya perbedaan kepentingan. Guna mengatasi perbedaan tersebut dibutuhkan adanya peraturan hukum yang mampu mengatur seluruh perikehidupan masyarakat dalam rangka mewujudkan rasa keadilan.

Hukum sebagai agent of change dalam kehidupan masyarakat seharusnya dapat mengatasi atau setidaknya telah mewaspadai segala bentuk perubahan sosial maupun kebudayaan yang menggejala didalam masyarakat yang kompleks. Sekalipun konsep-konsep hukum tersebut tidak sepenuhnya dipahami oleh masyarakat, tetapi hukum itu sendiri tetap eksis dalam konteks yang lebih universal. Hal ini tidak lain karena masyarakat umum yang menghendaki atau menciptakan suatu perubahan, meskipun tidak diiringi dengan pemahaman konsep yang menyeluruh.

Dalam hukum perdata di Indonesia masih bersifat pluralisme karena sampai saat ini masih berlaku hukum adat, hukum Islam dan hukum barat. Dari tiga sistem hukum tersebut, hukum Islam mempunyai kedudukan tersendiri, walaupun tidak seluruh hukum perdata Islam merupakan hukum positif di Indonesia, tetapi bidang-bidang penting hukum perdata Islam telah menjadi hukum positif. Bidang-bidang penting hukum perdata Islam dimaksud adalah hukum perkawinan, hukum kewarisan dan hukum perwakafan.

Hukum kewarisan merupakan bagian dari hukum kekeluargaan yang memegang peranan penting, bahkan menentukan dan mencerminkan sistem kekeluargaan yang berlaku dalam masyarakat. Hukum kewarisan sangat erat hubungannya dengan kehidupan manusia terkait dengan harta kekayaan dan manusia yang satu dengan yang lainnya, karena kematian atau meninggal dunia adalah peristiwa yang pasti akan dialami oleh seseorang. Kematian merupakan akhir dari perjalanan hidup seorang manusia. Jika orang yang meninggal dunia yang dikenal dengan pewaris meninggalkan keluarga dan harta kekayaan yang disebut warisan, dengan cara apa kita akan menyelesaikan atau membagi warisan yang ditinggalkan oleh pewaris serta hukum apa yang akan diterapkan untuk membagi warisan tersebut. Hukum yang membahas tentang peralihan harta peninggalan, pengurusan dan kelanjutan hak-hak dan kewajiban seseorang yang meninggal dunia diatur dalam hukum kewarisan.

Salah satu bentuk hukum yang diterapkan di Indonesia dalam mengatur hubungan hukum antara masyarakat Indonesia adalah Hukum Islam. Hukum Islam merupakan hukum yang bersumber dari al-Quran dan 
al-Hadist yang mengatur segala perbuatan hukum bagi masyarakat yang menganut agama Islam, salah satunya adalah mengenai kewarisan.

Pada kenyataannya bidang kewarisan mengalami perkembangan yang berarti. Hal ini disebabkan oleh kebutuhan masyarakat yang semakin kompleks dan pola pemikirannya bisa berubah sesuai dengan perkembangan zaman. Diantaranya hukum kewarisan Islam yang mengalami perkembangan dengan adanya ahli waris pengganti, yang penerapannya di Indonesia diatur dalam Kompilasi Hukum Islam (KHI).

Salah satu konsep pembaharuan hukum kewarisan Islam di Indonesia ditandai dengan lahirnya Kompilasi Hukum Islam melalui Intruksi Presiden Republik Indonesia Nomor 1 Tahun 1991 tanggal 10 Juni 1991 tentang Kompilasi Hukum Islam. Salah satu konsep pembaharuan hukum kewarisan Islam dalam Kompilasai Hukum Islam (KHI) adalah diberikannya hak seorang ahli waris yang telah meninggal dunia kepada keturunannya yang masih hidup. Aturan ini tercantum dalam pasal 185 Kompilasi Hukum Islam yang menjelaskan bahwa: ${ }^{1}$

1. Ahli waris yang meninggal lebih dahulu dari pada si pewaris maka kedudukannya dapat di gantikan oleh anaknya, kecuali mereka yang tersebut dalam pasal 173 .

2. Bagian bagi ahli waris pengganti tidak boleh melebihi dari bagian ahli waris yang sederajat.

Dalam hukum kewarisan Islam ada ahli waris pengganti, yang dalam beberapa hal berbeda dengan penggantian tempat ahli waris (plaatsvervulling) dalam hukum kewarisan KUHPerdata. Ketidak jelasan tersebut terkadang menimbulkan interpertasi yang berbeda sehingga implementasi tentang ahli waris pengganti ini juga diduga beragam.

\section{METODE PENELITIAN}

penelitian ini yaitu digunakan jenis penelitian kualitatif dengan metode studi kasus. Penelitian ini ditujukan untuk mengetahui penerapan ahli waris pengganti menurut Kompilasi Hukum Islam (KHI) di Pengadilan Agama Kabupaten Bone. Pemilihan lokasi ini didasarkan pada alasan bahwa Pengadilan Agama Kabupaten Bone tersebut dapat memberikan data-data dan keterangan yang berkenaan dengan masalah kewarisan khususnya tentang ahli waris pengganti.

${ }^{1}$ KompilasiHukumIslam (Yayasan Al-Hikmah Dan Ditbinbapera, 1998), h. 65. 


\section{HASIL PENELITIAN DAN PEMBAHASAN}

\section{A. Sistem Pewarisan Menurut Hukum Adat Kab. Bone}

Membahas mengenai realitas atau praktek yang terjadi dalam masyarakat dalam hal pembagian warisan, maka terlebih dahulu ditinjau dari teori atau aturan yang mengatur sebagaimana mestinya. Alquran sebagai sumber hukum Islam tertinggi yang bersifat universal bagi seluruh umat Islam yang tidak terbatasi oleh ruang dan waktu, yang mengatur berbagai macam aturan bagi manusia untuk bertindak yang dengannya dapat membedakan antara baik dengan buruk, benar atau salah, yang akan membawanya pada suatu titik yaitu kesempurnaan.

Hukum waris adat meliputi aturan-aturan dan keputusan-keputusan hukum yang bertalian dengan proses penerusan/pengoperan dan peralihan/perpindahan harta kekayaan materiil dan non materiil dari generasi ke generasi. Pengaruh aturan-aturan hukum lainnya atas lapangan hukum waris atas lapangan hukum waris dapat diwariskan.

Hukum waris adat itu mempunyai corak dan sifat-sifat tersendiri yang khas Indonesia, yang berbeda dari hukum Islam maupun hukum barat.Sebab perbedaannya terletak dari latar belakang alam fikiran bangsa Indonesia yang berfalsafah Pancasila dengan masyarakat yang bhineka tunggal ika.Latar belakang itu pada dasarnya adalah kehidupan bersama yang bersifat tolong-menolong guna mewujudkan kerukunan, keselarasan dan kedamaian didalam hidup.

Dari tingkah laku yang sering dilakukan, dalam hal ini mengenai suatu tindakan yang diterapkan dalam suatu kondisi kemudian menjadi kebiasaan/kultur masyarakat yang nantinnya akan berbeda dengan kultur kelompok masyarakat yang lain, yang secara turun-temurun akan dilaksanakan yang mungkin akan berbeda dengan apa yang telah diatur.

Istilah hukum waris adat atau bisa disebut hukum adat waris tidak ada bedanya. Istilah waris didalam kelengkapan istilah hukum waris adat diambil alih dari bahasa Arab yang telah menjadi bahasa Indonesia, dengan pengertian bahwa didalam hukum waris adat tidak semata-mata hanya akan menguraikan tentang waris dalam hubungannya dengan ahli waris, tetapi lebih luas dari itu. Sebagaimana telah dikemukakan diatas hukum waris adat adalah hukum adat yang memuat garis-garis ketentuan tentang sistem dan azas-azas hukum waris, tentang harta warisan, pewaris dan ahli waris serta cara bagaimana harta warisan itu dialihkan penguasaan dan pemilikannya dari pewaris kepada ahli waris. Hukum waris adat sesungguhnya adalah hukum penerusan harta kekeyaan dari suatu generasi kepada keturunannya. Dalam hal ini dapat diperhatikan bagaimana pendapat para ahli hukum adat dimasa lampau tentang hukum waris adat. 
Berdasarkan hasil wawancara denagan Narniati hakim di pengadilan Agama Kabupaten Bone, bahwa pembagian warisan tanpa melalui pengadilan bisa saja meskipun jumlah yang diterima tidak sama dengan jumlah yang seharusnya diterima, karena bagaimanapun perdamaian yang paling utama. Selanjutnya, Sumardi menambahkan bahwa perdamaian yang lahir dari kesepakan dari keluarga merupakan putusan yang paling tinggi nilainya karena dengan damai tidak akan ada pihak yang merasa dirugikan, berbeda halnya ketika suatu masalah diselesaikan melalui putusan pengadilan, akan ada pihak yang merasa dirugikan atas keputusan tersebut. ${ }^{2}$

Adapun ketika ahli waris yang lain merasa dirugikan atas keputusan yang telah dibuat, dapat mengajukan tuntutan ke Pengadilan Agama setempat, maka harta peninggalan tersebut akan dibagi sesuai aturan yang ada dan semua kerabat yang berhak menjadi ahli waris akan mendapat bagiannya termasuk orang tua meskipun posisi orang tua tidak menjadi penuntut bahkan orang tua tersebut tergolong tergugat.

Amiruddin (Hakim pengadilan Agama Kabupaten Bone), juga menambahkan pendapat dari Sumardi bahwa perdamaian merupakan hal yang tertinggi dan dapat mengesampingkan bagian yang seharusnya diterima oleh para ahli waris. Ketika suatu perkara hendak diselesaikan melalui pengadilan tanpa terkecuali termasuk masalah kewarisan, terlebih dahulu diupayakan mediasi melalui mediator yang ditunjuk oleh hakim untuk mendamaikan para pihak. Hal tersebut beradasarkan dengan peraturan Mahkama Agung Republik Indonesia No.1 Tahun 2008 tentang prosedur mediasi di pegadilan.Dalam dunia pengadilan, sebenarnya hanya ada satu hal pokok yang dicari para justiabalance (pencari keadilan) yaitu Putusan Hakim. Untuk lahirnya sebuah putusan diperlukan beberapa prosedur tententu, dan ada berbagai jenis putusan yang akan dilahirkan dari dunia peradilan. ${ }^{3}$

\section{B. Penerapan ahli waris pengganti menurut Pengadilan AgamaKab. Bone}

Sejak berlakunya Kompilasi Hukum Islam dan Undang-Undang Nomor 7 Tahun 1989 tentang Peradilan Agama yang terakhir diubah dengan UndangUndang Nomor 50 Tahun 2009 tentang Peradilan Agama, bagi orang-orang yang beragama Islam, dalam hal kewarisan, wasiat dan hibah, apabila ada sengketa

\footnotetext{
${ }^{2}$ Wawancara pada tanggal 18 Desember 2014.

${ }^{3}$ Wawancara pada tanggal 18 Desember 2014.
} 
dapat diselesaikan di Pengadilan Agama. Pengadilan Agama merupakan peradilan khusus di Indonesia dimana peradilan agama memerikasa dan mengadili perkaraperkara tertentu atau mengenai golongan rakyat tertentu, yakni perkara-perkara perdata tertentu dan hanya untuk orang-orang Islam. Bagi masyarakat Indonesia yang beragama Islam, dalam hal masalah kewarisan masih terdapat kebingungan dalam hal penyelesaiannya yakni melalui Pengadilan Agama dan Pengadilan Negeri. Dampaknya adalah bahwa banyak kasus kewarisan yang masuk di Pengadilan Negeri dan sekaligus masuk pula di Pengadilan Agama dimana putusannya sering pula berbeda oleh karena dasar hukum yang digunakan juga

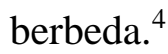

Dalam menyelesaikan kasus-kasus yang terjadi dalam masyarakat, Pengadilan Agama mendasarkan keputusannya pada ketentuan yang ada dalam Kompilasi Hukum Islam (KHI).Meskipun baru berupa Instruksi Presiden, namun ketentuan-ketentuan yang ada dalam Kompilasi Hukum Islam sudah digunakan layaknya undang-undang.Sebagaimana lembaga peradilan umum, tuntutan hak yang dapat diajukan di Pengadilan Agama dapat berupa permohonan dan dapat pula berupa gugatan.Pada kasus ini, tuntutan hak yang diajukan adalah hak mewaris dari ahli waris yang berupa permohonan penetapan ahli waris.

Pertimbangan putusan terdiri dari 2 (dua) bagian, yaitu pertimbangan tentang fakta hukum dan pertimbangan hukumnya itu sendiri. Pertimbangan tentang fakta diperoleh dengan cara memeriksa alat bukti secara empiris dalam persidangan. Fakta-fakta yang terungkap di persidangan selanjutnya diuji menggunakan teori kebenaran koresponden untuk memperoleh fakta hukum dan petunjuk.Sedangkan pertimbangan hukum merupakan bagian pertimbangan yang memuat uji verifikasi antara fakta hukum dengan berbagai teori dan peraturan perundang-undangan.Terbukti tidaknya suatu perkara di pengadilan sangat tergantung pada pertimbangan hukumnya.

Berdasarkan kasus (perkara) di Pengadilan Agama Watampone tahun 2013 dari permohonan, Majelis hakim Pengadilan Agama Watampone kemudian menetapkan ahli waris dari Almarhumah Andi Jare atas harta warisan berupa tanah dan empang yang terletak di Desa Cege Kecamatan Mare Kabupaten Bone. Permohonan ini diajukan dengan alasan bahwa harta warisan berupa tanah tersebut akan dibeli oleh pemohon sehingga untuk kelancaran proses jual belinya dan untuk kedepannya tidak akan ada sengketa kewarisan yang bisa melibatkan

${ }^{4}$ Roihan A. Rasyid, Kewenangan dan Acara Peradilan Agama Undang-Undang No. 7 Tahun 1989, (Bandung: Sinar Grafika, 1990), h. 5. 
pemohon, maka ditetapkan ahli waris yang berhak atas empang dan tanah tanah tersebut.

Permohonan penetapan ahli waris di Pengadilan Agama Watampone diajukan oleh Muh. Fulan bin Abd. Fulan dan Abd. Fulan bin Muh. Fulan sebagai pemohon. Dalam permohonannya, pemohon pada pokoknya bermohon agar Pengadilan Agama Watampone menetapkan ahli waris dari Almarhum Andi Lawang dan Almarhumah Andi Jare, dengan alasan bahwa almarhum dan almarhumah meninggalkan harta warisan berupa tanah dan empang yang terletak di Desa Cege Kecamatan Mare Kabupaten Bone, yang akan dijual oleh para Pemohon. Untuk maksud tersebut dan untuk kelancaran proses penjualan harta warisan tersebut, maka pemohon mengajukan permohnan penetapan ahli waris kepada Pengadilan Agama Watampone.

Berdasarkan Penetapan Pengadilan Agama Watampone Nomor 535/Pdt.G/2013/PA.Wtp.Tanggal 19 Desember 2013, diuraikan bahwa tanah harta warisan berupa tanah tersebut sebelumnya telah dibagi pada saat Andi Lawang meninggal dunia. Dalam penetapan Pengadilan Agama Watampone ini, yang menjadi Pewaris adalah Andi Jare sehingga bagiannya yang 81 bagian itu yang kemudian diwariskan kepada ahli warisnya sesuai dengan ketentuan yang berlaku.

Pasal 185 Kompilasi Hukum Islam boleh digunakan dalam hal tertentu saja, yakni apabila ada ahli waris yang dipandang tidak bisa memperoleh harta warisan atau belum berhak memperoleh harta warisan, sementara yang bersangkutan sangat dekat hubungan kekerabataanya (hubungan darah) dengan pewaris, misalnya cucu dari si pewaris. Dalam kasus seperti ini timbul 2 (dua) pendapat, ada yang mengatakan mereka dapat menggantikan ahli waris dan ada pula yang mengatakan mereka tidak dapat menggantikan ahli waris.Pandangan yang mengatakan bahwa cucu pewaris dipandang tidak berhak mendapatkan harta warisan karena masih ada kelompok ahli waris dzawwul furudh yang menutupinya.Namun demikian, ketentuan yang terpenting adalah bahwa ahli waris pengganti dapat menggantikan kedudukan ahli waris dzawwul furudh sepanjang ahli waris dzawwul furudh yang lebih dulu meninggal dunia dari pada si pewaris.

Dengan mempergunakan Pasal 185 tersebut sebagai dasar dalam pertimbangan hukum, maka bagian ahli waris tersebut dapat saja memperoleh bagian maksimal, yakni seperti sedianya akan diterima orang tuanya selama yang bersangkutan tidak terhalang untuk tampil menjadi ahli waris sebagaimana disebutkan dalam Pasal 173 Kompilasi Hukum Islam. Dalam pasal tersebut yang terhalang menjadi ahli waris adalah ahli waris yang telah dipersalahkan oleh pengadilan dan sudah berkekuatan hukum tetap karena alasan pembunuhan, atau 
mencoba melakukan pembunuhan, atau menganiaya berat pewaris, atau pun memfitnah pewaris.

Menurut Amiruddin, Hakim Pengadilan Agama Watampone bahwa anakanak si pewaris dianggap tidak efektif lagi untuk mendinding atau menutupi ahli waris lainnya, dalam hal ini cucu laki-laki dan wanita dari anak perempuan si pewaris yang telah meninggal terlebih dahulu sehingga mereka ditetapkan memperoleh bagian yang berasal dari bagian orang tuanya. Cucu dari pewaris masing-masing diangkat posisinya sebagai ahli waris efektif untuk mengganti kedudukan orang tuanya yang sudah meninggal lebih dahulu dari pewaris.Setelah penempatan tersebut, posisi cucu tersebut kedudukannya tidak disejajarkan dengan posisi anak-anak si pewaris sehingga ahli waris pengganti hanya memperoleh bagian dari bagian yang diterima oleh orang tuanya.Bagian orang tuanya inilah yang kemudian dibagi oleh si cucu berdasarkan porsinya masingmasing.

Menurut Yunus K (Hakim PA Watampone), bahwa ahli waris pengganti pada dasarnya adalah ahli waris karena penggantian, yaitu orang-orang yang menjadi ahli waris karena orang tuanya yang berhak mendapat warisan mati lebih dulu dari pada pewaris sehingga kedudukan orang tuanya digantikan olehnya. Jadi, Pasal 185 Kompilasi Hukum Islam bermakna selain penggantian tempat, juga bermakna derajat dan hak-hak tanpa membedakan dari garis keturunan lakilaki atau perempuan. Derajat yang dimaksud disini adalah bahwa ahli waris yang menggantikan kedudukan anak lak-laki memperoleh derajat yang sama dengan anak laki-laki, ahli waris yang menggantikan anak perempuan maka ia akan memperoleh derajat yang sama dengan anak perempuan yang digantikannya. Sedangkan hak yang dimaksud adalah bahwa apabila orang yang digantikan oleh ahli waris pengganti tersebut memperoleh warisan maka ahli waris pengganti juga berhak menerima warisan. ${ }^{5}$

Kompilasi Hukum Islam memberikan batasan mengenai bagian yang diterima oleh ahli waris pengganti sebagaimana diatur dalam Pasal 185 ayat (2) ompilasi Hukum Islam yang menyatakan bahwa bagian ahli waris pengganti tidak boleh melebihi dari bagian ahli waris yang sederajat dengan yang diganti. Berdasarkan Pasal 185 Kompilasi Hukum Islam, maka penulis berpendapat bahwa kedudukan cucu pada kasus ini dapat menggantikan kedudukan orang tuanya sebagai ahli waris. Berdasarkan Pasal 185 ayat (1) Kompilasi Hukum Islam, seseorang dapat mewaris karena penggantian tempat adalah:

${ }^{5}$ Wawancara pada tanggal 14 Desember 2014 
1. Orang yang digantikan oleh anaknya tersebut harus sudah meninggal dunia lebih dahulu dari pewaris.

2. Orang yang digantikan oleh anaknya tersebut merupakan ahli waris andaikata ia masih hidup.

Syarat pertama sudah sangat jelas bunyinya, sedangkan untuk syarat kedua harus dilihat bunyi ketentuan yang tertuang dalam Pasal 173 Kompilasi Hukum Islam. Pasal 173 Kompilasi Hukum Islam mengatur bahwa seseorang terhalang menjadi ahli waris apabilat erdapat putusan hakim yang telah mempunyai kekuatan hukum yang tetap, dihukum karena:

1. Dipersalahkan telah membunuh atau mencoba membunuh atau menganiaya berat pewaris.

2. Dipersalahkan secara memfitnah telah mengajukan pengaduan bahwa pewaris telah melakukan kejahatan yang diacam dengan hukuman 5 (lima) tahun penjara atau hukuman yang lebih berat.

Syarat lain yang meskipun tidak tersurat secara tegas dalam Kompilasi Hukum Islam tetapi harus dianggap ada adalah bahwa yang digantikan itu harus beragama Islam karena seorang cucu yang orang tuanya beragama selain agama Islam dan telah meninggal lebih dahulu daripada pewaris (kakek atau nenek si cucu) meskipun cucu tersebut beragama Islam, maka ia tidak dapat mewaris secara penggantian tempat oleh karena seandainya si orang tua tersebut masih hidup sesungguhnya ia tidak dapat menjadi ahli waris.

Dari hasil wawancara denganKamaluddin (Hakim Pengadilan Agama Kelas 1B Watampone), telah mengemukakan bahwa salah satu kendala yang dihadapi oleh para praktisi hukum, dalam hal ini hakim, dalam upaya penerapan ketentuan hukum waris Islam adalah peraturan hukumnya belum sempurna. Pedoman hakim dalam menjatuhkan putusan dalam perkara-perkara hukum waris Islam hanya berdasar pada Kompilasi Hukum Islam dan Yurisprudensi di luar Alquran dan Hadis.Sejauh ini, belum ada produk hukum baru yang mengatur secara eksplisit tentang hukum waris Islam.

Lebih lanjut Kamaluddin, mengemukakan bahwa peraturan hukum tentang kewarisan, khususnya ahli waris pengganti belum memasyarakat karena kurangnya sosialisasi dan atau penyuluhan hukum tentang hukum Islam. Hal tersebut dimungkinkan karena faktor fasilitas berupa sarana dan prasarana yang meliputi bahan penyuluhan hukum, dan kelancaran administrasi kurang mendukung, akibatnya berdampak pada rendahnya kesadaran masyarakat dalam mematuhi ketentuan ahli waris pengganti. ${ }^{6}$

${ }^{6}$ Wawancara pada tanggal 17 Desember 2014 


\section{PENUTUP}

\section{A. Kesimpulan}

1. Sistem pewarisan menurut hukumadat di Kabupaten Bone yaitu pembagian warisan tidak sesuai bagian yang semestinya diterima, dalam pembagian warisan diselesaikan secara musyawarah tanpa melalui Pengadilan Agama setempat. Meskipun pembagiannya tidak sesuai dengan bagian yang telah ditentukan dalam Al- Qur'an, namun dalam hukum Islam perdamaian merupakan hal yang tertinggi dan dapat mengesampingkan bagian yang seharusnya diterima oleh para ahli waris. Dan ketika suatu perkara hendak diselesaikan melalui Pengadilan Agama tanpa terkecuali termasuk masalah kewarisan, terlebih dahulu diupayakan mediasi melalui mediator yang ditunjuk oleh hakim untuk mendamaikan para pihak.

2. Penerapan ahli pengganti menurut Pengadilan Agama Kabupaten Bone yaitu pertimbangan Hakim dalam menetapkan ahli waris pengganti berdasarkan Penetapan Pengadilan Agama Watampone Nomor: 535/Pdt.G/2013/PA.Wtp. Tanggal 19 Desember 2013 yaitu cucu dapat menggantikan kedudukan orang tuanya sebagai ahli waris karena berdasarkan Pasal 185 ayat (1), seseorang dapat mewaris karena penggantian tempat adalah orang yang digantikan oleh anaknya tersebut harus sudah meninggal dunia lebih dahulu dari pewaris serta orang yang digantikan oleh anaknya tersebut merupakan ahli waris andaikata ia masih hidup. Selain itu, syarat yang paling penting adalah bahwa baik pewaris yang sebenarnya maupun ahli waris pengganti harus beragama Islam.

\section{B. Saran}

1. Untuk mengatasi kendala dalam pelaksanaan hukum kewarisan termasuk ketentuan ahli waris pengganti, diharapkan kepada seluruh pihak yang terkait agar lebih meningkatkan sosialisasi tentang hukum waris Islam agar ketentuan hukum dan aturan yang telah ditetapkan dalam Alquran dapat diiplementasikan dalam kehidupan masyarakat.

2. Diperlukan adanya undang-undang yang mengatur tentang hukum waris Islam selain Kompilasi Hukum Islam. Ketentuan dalam Kompilasi Hukum Islam tentang waris mewaris harus disempurnakan agar tercipta kesamaan persepsi dari kalangan penegak hukum. 


\section{DAFTAR PUSTAKA}

Al Qur'an Karim.

A. Pitlo, Hukum Waris Menurut Kitab Undang-Undang Hukum Perdata Belanda, "Terj. M. Isa Arief". Jakarta: PT. Intermasa, 1986.

Ali, Mohammad Daud. Asas-asas Hukum Islam "Pengantar Ilmu Hukum dan Tata Hukum Indonesia”. Jakarta: Rajawali Press, 2000.

Al-Jalidi, Said Muhammad. Ahkam al-Miraswa al-Washiyyah fi al-Syari'ah al-Islamiyyah. Mansurat Kulliyah al-Dakwah.

Ash-Shabuni, M. Ali hamid. Hukum Waris. Jakarta: Pusta Mantiq,1994.

Ash- Shiddieqy, Tengku Muhammad Hasbi. FiqhMawaris. Semarang: Pustaka Rizki Putra, 1997.

Aulawi, Wasit. Sistem Penggantian dan Pengelompokan Ahli Waris, Hukum Kewarisan dalam Kompilasi Hukum Islam. Makalah Seminar, UI Depok 12 Desember 1992.

Bashori, Subchan Al-Faraidh Cara Mudah Memahami HukumWaris Islam. Jakarta: Nusantara Publisher, 2009.

Basri, CikHasan. Peradilan Agama Di Indonesia. Cet. IV; Jakarta: RajawaliPers, 2003.

Budiono, Rachmad. Pembaruan Hukum Kewarisan Islam di Indonesia. Bandung: Citra AdityaBakti, 1999.

Djubaedah, Neng, Soelistijono,Yati N. Hukum Kewarisan Islam di Indonesia. Cet. 2; Depok: BadanPenerbitFakultasHukumUniversitas Indonesia, 2008.

Hazairin.Hukum Kewarisan Bilateral Menurut Qur'an Dan Hadits. Jakarta: Tintamas, 1964.

Harahap,M. Yahya. Pokok-Pokok Materi Kewarisan dalam KHI, Hukum Kewarisan Islam dalam Kompilasi Hukum Islam. Makalah seminar, UI Depok 12 Desember 1992.

Hilman Hadikusuma, Hukum Waris Adat, Bandung: P.T Citra AdityaBakti 1993, hlm 7

Hilman Hadikusuma, Hukum Waris Adat, Bandung: Alumni 1983, hlm 8

Isuma. Penggantian Tempat Dalam Hukum Waris Menurut KUHPerdata, Hukum Adat, dan Hukum Islam. Cet. I; Jakarta: Bulan Bintang, 1978.

Kompilasi Hukum Islam, Yayasan Al-Hikmah Dan Ditbin bapera, 1998.

Lubis, Suhrawardi K, Simanjuntak, Komis. Hukum waris Islam (lengkap dan Praktis). Jakarta: SinarGrafika, 1999.

Parman, Ali. Kewarisan dalam Al-Qur'an: Suatu Kajian Hukum Dengan Pendekatan Tafsir Tematik. Jakarta: PT. Raja GrafindoPersada, 1995.

Perangin, EffendI. HukumWaris. Jakarta: PT.Raja GrafindoPersada, 1997. 
Ramulyo, M. Idris .Perbandingan Hukum Kewarisan Islam dengan Kewarisan KitabUndang-undang HukumPerdata.Jakarta: SinarGrafika, 2004.

Sudarsono, Hukum Waris dan Sistem Bilateral. Jakarta: PT.Rineka Cipta, 1991.

Usman, Suparman. Ikhtisar Hukum Waris Menurut Kitab Undang-Undang hukumPerdata( Burgerlijk Wetboek). Serang: Darul Ulum Press. 1993.

Thalib, Sajuti. Hukum Kewarisan Islam di Indonesia. Jakarta :Bina Aksara, 1982.

Wirjono Prodjodikoro, 1983, Hukum Waris di Indonesia, Cetakan II, Sumur, Bandung, hal 16 